\title{
DURING THE CORONAVIRUS (COVID-19) PANDEMIC, DOES WEARING A MASK IMPROVE OR WORSEN PHYSICAL PERFORMANCE?
}

\author{
DURANTE A PANDEMIA DE CORONAVÍRUS (COVID 19), O USO DE MÁSCARA MELHORA OU PIORA \\ ODESEMPENHO FÍSICO?
}

\author{
¿DURANTE LA PANDEMIA DE CORONAVIRUS (COVID 19) EL USO DE LA MÁSCARA MEJORA \\ O EMPEORA EL DESEMPEÑO FISICO?
}

\author{
Paulo Roberto Santos-Silva' (iD \\ (Physical Education Professional) \\ Júlia Maria D’Andrea Greve' (DD \\ (Physician) \\ André Pedrinelli i (D) \\ (Physician)
}

1. Universidade de São Paulo, Faculdade de Medicina, Orthopedics and Traumatology Department, Laboratory for Studies in Movement (LEM- HCFMUSP), SP, Brazil.

\section{Correspondência}

Júlia Maria D'Andréa Greve. Avenida Pacaembu, 1777. São Paulo, SP, Brazil. 01234-001. jgreve@usp.br

\begin{abstract}
A mask is a simple device yet it provides high levels of protection. As the virus affects mainly the respiratory tract - the nose, mouth, and lungs - it is highly contagious when people sneeze or cough, or exchange respiratory droplets with other people. This exchange is also promoted when a person is performing physical exercise. Although a mask provides some protection, it does not eliminate the need for social distancing. Around $25 \%$ of people infected with the new coronavirus may show no symptoms, yet still transmit the virus. One of the main problems with wearing a mask is that it hinders breathing, with the mask gradually becoming damp, increasing its resistance to air intake. Wearing a mask while performing physical activity requires a period of adaptation, as the flow of air to the lungs is reduced, requiring a reduction in the normal rhythm until the wearer has managed to adapt to it. Vigorous and intense exercise can cause inflammatory activity to increase, and should be minimized in order to protect the immune system. Secretory immunoglobulin A ( $\lg A)$ is an antibody protein used by the immune system to neutralize pathogens, including viruses, and decreases with intense exercise. Exercise is considered intense when it is necessary to breathe through the mouth to eliminate the higher concentrations of $\mathrm{CO} 2$, but mouth breathing is associated with infections of the upper respiratory tract. Preference should be given to light to moderate exercise, around three times a week. Wearing a mask, and training in nasal breathing are the best and safest ways to reduce the entry of particles, and should be encouraged during this COVID-19 pandemic. Level of evidence V; Opinion of the specialist.
\end{abstract}

Keywords: SARS-CoV 2; Exercise; Sports activity.

\section{RESUMO}

A máscara éum dispositivo simples, mas oferece altos niveis de proteção. Como o vírus afeta principalmente o trato respiratório - nariz, boca e pulmões - éaltamente contagioso quando as pessoas espirram, tossem ou trocam gotículas respiratórias com outras pessoas. Essa troca também é promovida quando a pessoa está realizando exercícios físicos. Embora a máscara forneça alguma proteção, ela não elimina a necessidade de distanciamento social. Cerca de 25\% das pessoas infectadas com o novo coronavírus podem não apresentar sintomas, mas mesmo assim, transmitem o vírus. Um dos principais problemas do uso de máscara éque ela dificulta a respiração, pois gradualmente fica úmida e aumenta a resistência à entrada de ar. Énecessário um período de adaptação para a atividade física com máscara, pois o fluxo de ar para os pulmões éreduzido, exigindo a diminuição do ritmo normal até que a adaptação ocorra. Exercícios vigorosos e intensos podem aumentam a atividade inflamatória e devem ser minimizados para proteger o sistema imunológico. Aimunoglobulina secretora A (IgA) éuma proteína anticorpo usada pelo sistema imunológico para neutralizar patógenos, incluindo vírus, e diminui com exercícios intensos. O exercício é considerado intenso quando é necessário respirar pela boca para eliminar a maior concentração de $\mathrm{CO}$, mas a respiração bucal está associada a infecções do trato respiratório superior. A preferência deve ser pelos exercícios leves a moderados, realizados cerca de três vezes por semana. Usar a máscara e treinar a respiração nasal são os modos melhores e mais seguros de reduzir a entrada de partículas e precisam ser incentivados durante a pandemia de COVID-19. Nível de evidência V; Opinião do especialista.

Descritores: SARS-CoV 2; Exercício físico; Atividade esportiva.

\section{RESUMEN}

La máscara es un dispositivo simple, pero ofrece altos niveles de protección. Debido a que el virus afecta principalmente el tracto respiratorio (nariz, boca y pulmones) es muy contagioso cuando las personas estornudan, tosen o intercambian gotitas respiratorias con otros. Aunque la máscara proporciona cierta protección, no elimina la necesidad del distanciamiento social. Alrededor del 25\% de las personas infectadas con el nuevo coronavirus pueden no tener síntomas, pero aun así transmiten el virus. Uno de los principales problemas de la máscara es que dificulta la respiración, ya que gradualmente se humedece y aumenta la resistencia a la entrada del aire. Es necesario un período de adaptación para la actividad física con una máscara, ya que reduce el flujo de aire a los pulmones, lo que requiere una disminución del ritmo normal hasta que se produzca la adaptación. El ejercicio vigoroso e intenso puede aumentar la actividad inflamatoria y debe minimizarse para 
proteger el sistema inmunitario. La inmunoglobulina secretora A (IgA) es una proteína anticuerpo utilizada por el sistema inmunitario para neutralizar los patógenos, incluidos los virus, y disminuye con el ejercicio intenso. El ejercicio se considera intenso cuando es necesario respirar por la boca debido la mayor concentración de CO2, pero la respiración bucal se asocia con infecciones del tracto respiratorio superior. La preferencia debe ser para la realización de ejercicios leves a moderados aproximadamente tres veces por semana. Usar la máscara yentrenar la respiración nasal es mejory más seguro para reducir la entrada de partículas y deben estimularse durante la pandemia de COVID-19. Nivel de evidencia V; Opinión de expertos.

Descriptores: SARS-COV 2; Ejercicio físico; Actividad deportiva.

\section{INTRODUCTION}

The lack of information on the etiology and pathology of the pandemic corona virus (COVID-19) was the foreshadowing that masks would become a precious commodity. ${ }^{1}$ Masks are very good protective tools in blocking larger droplets and not so good at blocking small particles. When a person expels droplets into the air, they quickly evaporate and shrink, becoming small airborne particles, called droplet nuclei. These are extremely difficult to remove from the air. However, in the humid atmosphere between a person's mouth and his mask, it takes almost a hundred times as long for a drop to evaporate and shrink at its core. In practice this means that almost any type of simple cloth mask is excellent for controlling the source of the infectious agent. Although the exact size of the droplets produced is still debated, most sources agree that talking, coughing and sneezing produce droplets small enough to remain in the air.?

For COVID-19, the virus was found in the air more than a meter and a half away from the patient, in ventilation systems and even in the air of the corridors outside the patients' rooms, indicating the potential for airborne propagation. ${ }^{3}$ Another study showed that the viral RNA remained in the air up to 4 meters from the patient. ${ }^{4}$ However, the presence of RNA does not mean that there are viable viruses, nor that he was present in numbers large enough to cause clinical infection. That said, if COVID-19 is aerosolized in large volumes, it is likely that the virus will remain viable for at least 3-5 hours. ${ }^{5}$

Therefore, due to the potentially fatal nature of the virus, the debate quickly became emotional. The coronavirus is called with that name because the central envelope is surrounded by small spikes of proteins called peplomers that mediate virus-cell interaction. ${ }^{6}$ They wreak havoc when they bind to lung tissue and steal healthy tissues to form a potentially lethal army of coronavirus invaders. As the virus installs mainly in the respiratory tract - nose, mouth and lungs - it is highly contagious when people sneeze, cough or exchange respiratory droplets with other people and thus the mask has an important protective function. Dogmatic ideologies, often based on limited science, led people to question and stigmatize those who dared to disagree. Face masks have come a long way since the 19th century, when they were basically strips of gauze placed over the mouth. The first study only appeared through Walker (1930) ${ }^{7}$, when concerned with the high number of deaths, researched the use of masks in surgeries in 100 hospitals. Originally, they were developed to minimize the risk of transmission of microorganisms to the patient, but now, they have the dual mission of protecting patients and health professionals against pathogens transmitted by blood, breathing and / or other body fluids. ${ }^{8-10}$

The COVID-19 pandemic also raised doubts about the practice of physical activity such as walking, running, gymnastics, dancing, cycling, among others, wearing a mask and how it affects breathing, reduces performance or increases the possibility of contagion. ${ }^{11}$ Even with a lack of accurate information about how the virus spreads - potentially through the air and people without symptoms, it puts physical activity in the midst of distrust. Undoubtedly, one of the main difficulties is the discomfort to breathe. There is a need for an adaptation period to do physical activity with a mask. ${ }^{11}$ The pace will be slower and tiredness appears more quickly, associated with the unpleasant sensation of humidification of the mask with the progression of the activity. Compared to normal breathing, wearing any type of protective mask decreases the flow of air to the lungs. Less oxygen in the lungs means less oxygen in the blood and muscles, which makes training difficult. There is less oxygen available to use during exercise to convert glucose [sugar] into energy. Thus, physical activity with a mask or any other type of facial coverage is more difficult, because it is necessary to breathe more to get the same amount of air in the lungs. ${ }^{12-13}$ But running with a mask is not an entirely new concept either. The use of training masks can improve lung capacity and oxygen efficiency, simulating high altitude conditions. ${ }^{14}$

Although there are controversies about the real benefits of altitude masks, there are doubts as to whether the same principle could be applied to cloth masks. However, this depends on some factors, among which, the most important is the place where physical activity is performed (with or without agglomeration).

Concerning the current pandemic, the US Disease Control Center (CDC/USA) guideline recommends the use of facial cloth coverings in public places where other social distance measures are difficult to maintain, for example, parks, squares, supermarkets and pharmacies with a lot of agglomeration (Figure 1). About 25\% of people infected with the new COVID-19 may have no symptoms and transmit the virus. ${ }^{15}$

\section{Use of the facemask at the gym?}

Recently, Korean researchers have shown that vigorous exercise in confined spaces should be minimized. ${ }^{6}$ In the Korean experience,
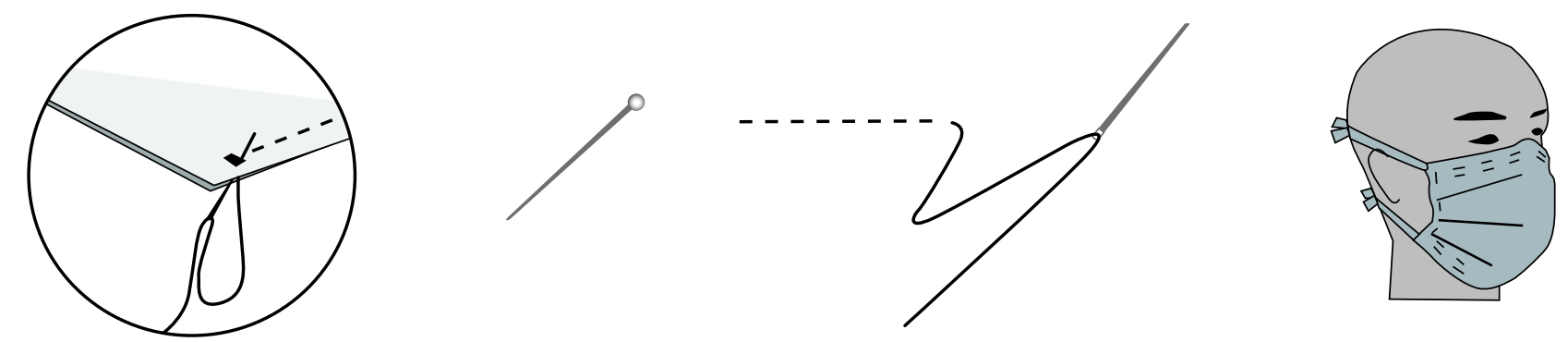

Figure 1. Sewing pattern of masks for use with common household materials. 
112 people were infected with COVID-19. All were related to dance classes at 12 sports facilities. At the time of confirmation, 82 (73.2\%) had symptoms, with 30 (26.8\%) remaining asymptomatic. On average, students developed symptoms three and a half days after attending a dance class. It was found that $50.9 \%$ of cases involved transmission from instructors to students during classes, which lasted 50 minutes twice a week. They also concluded that 33.9\% were from family transmission from instructors and students and 15.2\% were from transmission during meetings with co-workers or acquaintances. ${ }^{16}$ Inefficient ventilation, high levels of $\mathrm{CO}_{2}$, humidity and high temperature in a gym combined with turbulent air generated by intense physical exercises can cause more dense transmission of isolated droplets causing high risks of infections such as influenza, tuberculosis, COVID-19, etc. ${ }^{17-18}$ However, lighter practice classes like yoga and Pilates that occurred in the same rooms did not transmit the virus. ${ }^{16}$

The general rule of thumb is to wear a mask while exercising in areas populated by other people, who could potentially be contaminated. However, walking or running alone in open areas or without crowds, keeping a distance of at least $1.5 \mathrm{~m}$, is also potentially safe and does not require the use of masks, but still without scientific proof. However, with agglomerations, the use of the mask is essential. The droplets of saliva and other fluids emitted by people during exercises remain in the air, forming a "cloud" that will be "crossed" by whoever is behind or in the opposite direction if it is too close. Researchers at the Catholic University of Leuven, Belgium, and the Eindhoven University of Technology in the Netherlands recommend that people keep up to 20 meters away from each other in outdoor exercise, depending on the activity. It is important to note that using a facemask does not replace physical distance, it is necessary to keep it during activities. The risk of being infected is estimated at $13 \%$ within $1 \mathrm{~m}$, but only $3 \%$ beyond that distance. One study says that for every extra meter of up to $3 \mathrm{~m}$ the risk is halved. ${ }^{19}$

\section{Is it mandatory to wear a mask while exercising outdoors?}

In this condition, the viral spread has no consistency, it seems more myth than truth. However, where and under what circumstances people need to wear a mask while exercising outdoors weighs heavily on the environment and health conditions. In general, exercising outdoors, with or without a mask, seems safe, according to most experts. ${ }^{7}$ A relatively little transmission of COVID-19 would occur outdoors, except perhaps in large crowds due to the increased volume of breathing rate that would help the virus spread the drops. Although there is a risk, social detachment is safer. In this sense, some distance rules have been adopted by several countries: from $1 \mathrm{~m}$ - China, Denmark, France, Hong Kong, Lithuania, and Singapore; 1.4m - South Korea; 1.5m - Australia, Belgium, Germany, Greece, Italy, Holland, and Portugal; 1.8m - USA; 2 m - Canada, Spain, and the United Kingdom. However, following the guidance of the American $\mathrm{CDC}^{15}$ and for prevention, you should cover your face while exercising outdoors. Besides, masks have an important psychological protection aspect to reassure people with whom you share paths or sidewalks while doing physical activity. ${ }^{20-21}$

\section{Does wearing a mask make walking, running, or cycling difficult?}

The answer is yes. It was the finding of a study evaluating exercise in extreme environments. ${ }^{14}$ She studied the effects on athletes wearing specialized masks that restrict airflow and simulate altitude training. Above all, depending on the thickness of the mask cloth, the resistance to airflow increases. Another study by Eijsvogels et al. ${ }^{13}$ who studied the regulation of heat and the breathing of athletes shares the opinion of Bellovary. ${ }^{14}$ Research has shown that if the mouth and nose are fully covered, there may be some limitations to the air intake, which can increase discomfort and mitigate running performance. Another important aspect is the humidity caused by breathing on the masks, which increases the resistance to the entry of air. Also, wet masks lose antimicrobial efficiency. ${ }^{15}$ The exercise will create a hot, moist microclimate around your face as the mask holds your exhaled breath. ${ }^{12}$

\section{Does mask work as hypoxic training?}

The regular mask does not work as a hypoxic training (with thin air, low oxygenation). The altitude training masks are designed to intentionally restrict the amount of oxygen in the air that the user inhales. ${ }^{12}$ The valve is adjustable and allows the user to increase and decrease the resistance to breathe oxygen, but without the presence of rarefied air. Therefore, over time, users can train to run with lower levels of oxygen saturation and thus increase their oxygen efficiency, but without the thin air. With the common mask, the amount of air that enters the lungs is still composed of the same proportion of oxygen (20.93\%), which is the concentration at sea level, that is, the air is not rarefied. At sea level, the air pressure is about $1 \mathrm{~kg}$ per square centimeter. At 10,000 feet $(3 \mathrm{~km})$, the air pressure is 10 pounds per square inch $(0.7 \mathrm{~kg}$ per square $\mathrm{cm}$ ). There is also less oxygen to breathe. Because the air pressure is $30 \%$ lower at the highest altitude due to the fact that the atmosphere is less dense - that is, the air molecules are further apart. The percentage of oxygen in the air is essentially the same as that at sea level (20.93\%). ${ }^{22}$

With the cloth mask, a runner is not altering the oxygen saturation of the air, but only breathing less of that air due to the resistance imposed by the mask. However, air resistance increases, and an adaptation period is needed. This means that the muscles in the lungs need to exert more force to obtain the same amount of air they were used to without the mask. An advantage, obtained with the use of the mask, is the strengthening of the respiratory muscles. The use of the mask causes an increase in heart rate and improves the strength of the diaphragm.

\section{Disadvantages of the mask}

The material that covers the nose and mouth will gradually become moist, due to the sweat and water vapor from the lung exhalations. According to Lipman ${ }^{12}$, the mask transforms the lower half of the face into a "mini sauna", leading to the accumulation of sweat under the mask and an increase in nasal secretions. In addition to discomfort, the effectiveness of the mask may decrease. One of the ways to reduce this effect is to use only nasal breathing, as the exhalation through the nose produces fewer drops of water than mouth breathing, keeping the mask drier. Another benefit of nasal breathing is the greater filter effect of the cavities in relation to allergens and foreign bodies in the air. The body has this built-in filtering system, little used by the greater use of mouth breathing, which can further help in protecting against the viral particles of the breathed air. ${ }^{12}$

Nasal breathing also gives the lungs more time to extract oxygen from the absorbed air, because exhalation is slower, so there is the importance of using this type of breathing. Nasal breathing is challenging and needs to be introduced gradually with training, as the nostrils are small and hold a little volume of air.

\section{Is it possible to maintain nasal breathing for a long time?}

It is not possible at high exercise intensities, because when the effort exceeds the second ventilatory threshold $\left(\mathrm{VT}_{2}\right)$, there will be a rapid reduction in blood $\mathrm{pH}$, which represents a point where the release of $\mathrm{CO}_{2}$ is no longer adequate to inhibit the production of acidosis above of $\mathrm{VT}_{2}$, even in trained people, this response occurs, however later on. ${ }^{23}$ In this case, the presence of mouth breathing will be inevitable.

The pace is the first thing that a walker or runner must control with the use of the mask, as the same amount of effort will result in less physical 
production. Therefore, the recommendation is to keep the pace slow and manageable while getting used to the mask. It is recommended to use the mask in other daily activities, not just during running, to get into the habit and condition your lungs during exercise.

\section{Is there an advantage to dropping the mask?}

The mask decreases performance in the first times of use, but over time an adaptation will occur. The use of the mask for weeks or months increases the strength of the lung muscles. ${ }^{24-25}$ With the removal of the mask, the lungs will have the ability to absorb more oxygen and possible performance improvement. This response is similar to the effect of performing the exercise on a flat course after several weeks of uphill training. Your body adapts to the most difficult conditions and will probably perform better as soon as you return to the easiest condition (without the mask). It is important to maintain a manageable, tolerable, mentally controlled exercise routine that follows the rules of social detachment. The benefits of physical activity remain, even with the difficulties that the use of the mask brings.

\section{FINAL CONSIDERATIONS}

The mask causes discomfort and decreases performance a little and requires adaptation time. The mask remains moist and increases the resistance to the flow of air to the lungs, requiring more effort for the respiratory muscles, but serves as a barrier to the particles. The use of the mask works as a nasal breathing training and is better and safer to reduce the entry of particles and needs to be encouraged during this pandemic period of COVID-19.

All authors declare no potential conflict of interest related to this article

AUTHORS' CONTRIBUTIONS: Each author made significant individual contributions to this manuscript. PRSS: writing and literature review, and JMG and AP: correction and revision of the text.

\section{REFERENCES}

1. Greenhalgh T, Schmid MB, Czypionka T, Bassler D, Gruer L. Face masks for the public during the covid-19 crisis. BMJ. 2020;m1435.

2. Fiegel J, Clarke R, Edwards DA. Airborne infectious disease and the suppression of pulmonary bioaerosols. Drug Discov Today. 2006; 11(1): 51-57.

3. Ong SWX, Tan YK, Chia PY, Lee TH, Ng OT, Wong MSY, et al. Air, surface environmental, and personal protective equipment contamination by severe acute respiratory syndrome coronavirus 2 (sars-cov-2) from a symptomatic patient. JAMA. 2020; 323(16):1610-1612.

4. Guo Z, Wang Z, Zhang S, Li X, Li L, Li C, et al. Aerosol and surface distribution of severe acute respiratory syndrome Coronavirus 2 in Hospital Wards, Wuhan, China, 2020. Emerg Infect Dis. 2020;26(7):1583-1591.

5. van Doremalen N, Bushmaker T, Morris DH, Holbrook MG, Gamble A, Williamson BN, et al. Aerosol and surface stability of SARS-CoV-2 as compared with SARS-CoV-1. N Engl J Med. 2020; 382:1564-1567.

6. Belouzard S, Millet JK, Licitra BN, Whittaker GR. Mechanisms of Coronavirus Cell Entry Mediated by the Viral Spike Protein. Viruses. 2012; 4(6): 1011-1033.

7. Walker IJ. How can we determine the efficacy of the surgical mask? Surg Gynecol Obstet. 1930; 50: 266-70.

8. Belkin, NL. A century after their introduction, are surgical masks necessary? AORN Journal. 2006; 64 (4):602-7.

9. Belkin NL. The surgical mask has its first performance standard--a century after it was introduced. Bull Am Coll Surg. 2009; 94(12):22-5.

10. PAHO: Pan American Health Organization. Prevention and control of healthcare - associated infections. Basic Recommendations. Washington, D.C.: PAHO; 2018.

11. Skaria SD, Smaldone GC. Respiratory source control using surgical masks with nanofiber media. Ann Occup Hyg. 2014; 58(6): 771-781

12. Lipman GS, Kanaan NC, Phillips C, Pomeranz D, Cain P, Fontes K, et al. Study Looking at End Expiratory Pressure for Altitude IIIness Decrease (SLEEP-AID). High Alt Med Biol. 2015; 16:154-161.

13. Eijsvogels TMH, Molossi S, Lee DC, Emery MS, Thompson PD. Exercise at the extremes: the amount of exercise to reduce cardiovascular events. J Am Coll Cardiol. 2016; 67:316-29.

14. Bellovary BN, King KE, Nuñez TP, McCormick JJ, Wells AD, Bourbeau KC, et al. Effects of high-intensity interval training while using a breathing-restrictive mask compared to intermittent hypobaric hypoxia. J Hum Sport Exerc. 2019; 14(4): 821-33.

15. CDC/USA, 2020. Recommendation regarding the use of cloth face coverings, especially in areas of significant community-based transmission.

16. Jang S, Han SH, Rhee J-Y. Coronavirus disease cluster associated with fitness dance classes, South Korea. Emerg Infect Dis. 2020; 26(8)

17. Cowling BJ, Ali ST, Ng TWY, Tsang T, Li JCM, Fong MW, et al. Impact assessment of non-pharmaceutical interventions against coronavirus disease 2019 and influenza in Hong Kong: an observational study. Lancet Public Health. 2020; 5: e279-288.

18. Li Y, Leung PHM, Yao L, Newton E. Antimicrobial effect of surgical masks coated with nanoparticles. Hosp Infect. 2006; 62(1):58-63.

19. Chu DK, AkI EA, Duda S, Solo K, Yaacoub S, Schunemann HJ, et al. Physical distancing, face masks, and eye protection to prevent person-to-person transmission of SARS-CoV-2 and COVID-19: a systematic review and meta-analysis. Lancet. 2020; (20)31183-1

20. Liu X, Zhang S. COVID-19: Face masks and human-to human transmission. Influenza Other Respir Viruses [Internet]. 2020 Mar [cited 2020 Apr 8]. Available from: https://doi.org/10.1111/irv.12740

21. Cowling BJ, Zhou Y, Ip DKM, Leung GM, Aiello AE. Face masks to prevent transmission of influenza virus: a systematic review. Epidemiol Infect [Internet]. 2010 Jan [cited 2020 Apr 8]; 138(4):449-56. Available from: https://doi.org/10.1017/\$0950268809991658

22. Peacock AJ. ABC of oxygen. Oxygen at high altitude. BMJ. 1998; 317(7165): 1063-1066.

23. Wasserman K, Whipp BJ. Exercise physiology in health and disease. Am Rev Resp Dis. 1975; 112 (2):219-49.

24. Porcari JP, Probst L, Forrester K, Doberstein S, Foster C, Cress ML, Schmidt K. Effect of Wearing the elevation training mask on aerobic capacity, lung function, and hematological variables. J Sports Sci Med. 2016; 15(2): 379-86.

25. Jagim AR, Dominy TA, Camic CL, Wright G, Doberstein S, Jones MT, et al. Acute effects of the elevation training mask on strength performance in recreational weightlifters". J Strength Cond Res Online. 2018; 32(2): 482-89. 